УДК 616.717/718-089.1:541.64

DOI: $10.24061 / 1727-0847.16 .1 .2017 .25$

\author{
O.G. Dudko, I.V. Storoschuk, V.V. Pickula, Yu.V. Strashok, M.I. Ribak, S.M. Alkamel, \\ N.B. Reshetilova \\ Higher State Educational Institution of Ukraine "Bukovinian State Medical University”, Chernivtsi
}

\title{
THE LONG TERM FOLLOW-UP OF INTERNAL FRACTURE FIXATION WITH METAL VERSUS POLYMERIC FIXATION DEVICES
}

\section{ВІДДАЛЕНІ РЕЗУЛЬТАТИ ЛІКУВАННЯ ХВОРИХ, ОСТЕОСИНТЕЗ ЯКИМ ПРОВОДИВСЯ МЕТАЛЕВИМИ ТА ПОЛІМЕРНИМИ ФІКСАТОРАМ}

Резюме. Проведені дослідження, з застосуванням клінічних та рентгенологічних обстежень доводять, що патологічних змін кісткової тканини в ділянках синтезованих консолідованих метаепіфізарних переломів в оперативному лікуванні яких застосовувалися фіксатори, виготовлені 3 полімерних матеріалів полігліколіду та поліаміду П-12, не виявлено на протязі всього терміну спостережень від 10 до 44 років після оперативного втручання. Обидва полімерні матеріали виявлять високу біосумісність, що дозволяє безпечно застосовувати фіксатори виготовлені з даних матеріалів для остеосинтезу метаепіфізарних переломів.

Ключові слова: остеосинтез переломів, біодеградуючі імплантати, полігліколід, поліамід-12, довготривалі спостереження.

Polymeric fixation devices for surgical treatment of closed limb fractures can be a good alternative to metal fracture fixation devices [1]. Currently the implants made of stainless steel (316L, 1X18N9T), titanium, and titanium alloys have become widespread in the surgery, but there's a disadvantage of their application requiring the second surgical procedure, aimed to remove them afterwards $[2,3]$. As for the polymeric devices, some of them are biodegradable, while others are bioinert due to the absence of corrosion, and therefore do not require the removal [4]. Just a few research reports exist, that are devoted to studying the consequences of the use of polymeric fixation devices with follow-up periods spanning from 1 to 5 years only, while further results for most of the polymeric materials normally remain untraced and therefore unknown $[5,6]$.

Objectives: to determine changes of bone tissue in healed fracture areas after internal fixation with the use of polymeric or metal fixation devices in far outcome through applying clinical and radiological examination.

Design and Methods. The study involved 157 patients with fractures of limbs that were randomized in three groups before the surgery. All patients in the same group were treated using the fixation device, produced of the same material. Fixation devices made of polyglycolide were used in 37 cases, of polyamide-12 in 62 cases, and of metal in 58 cases. The patients were followed-up clinically and radiologically (X-ray, CAT, MRI) during the periods, lasting 10-44 years.

Results. The results of fracture treatment, using polymeric devices, were compared with the results of surgeries, where the devices made of stainless steel were employed. Changes of the tissues in the place of the fixation were examined using clinical and radiological methods and evaluated with the help of our own estimation score system. The system in question has included 8 clinical and 3 radiological criteria to form a three grade scale. Good results in 20-30 years after polymeric osteosynthesis with polyglycolide were achieved in $92.6 \%$, while in $7.4 \%$ of cases the results turned out satisfactory. In group of patients, operated with the use of polyamide-12 fixation devices, good results were achieved in $77.4 \%$ of cases, while good results in patients after internal fracture fixation with metal fixation devices totalled $71.4 \%$.

Discussion. There was a complete restoration of bone structure in the place of polyglycolide implantation without any pathological formations or other changes. Polyamid-12 polymeric devices were covered with capsule of bone tissue similar to cortical layer. The diameter of polyamide- 12 screws was decreased by one third, compared with the initial one. Metal fixation devices were removed in $78.2 \%$ cases. In most of the cases the presence of metal fixation devices caused no problems, though there was one case 
of infection and three cases of the fixation device migration occurred. In two cases during the removal procedure some screws or their parts had to be left inside due to removal problems.

Conclusion. Both polymeric materials (polyglycolide and polyamide-12) revealed high extent of biological compatibility. Polymeric fixation devices have produced any negative effect on normal physiological regeneration of the bone tissue at the fractured segment and a patient's organism overall within up to 44 years of follow-up. Therefore these materials can be safely used for production of bone fixation devices for internal fixation fractures of methaepyphyseal areas.

\section{References}

1. Biorezorbiruemyie polimeryi v ortopedii i travmatologii / V.A. Radchenko, N.V. Deduh, S.V. Malyishkina, L.M. Bengus // Ortopediya, travmatologiya i protezirovanie. - 2006. - № 3. - S. 116-124. 2. Kombinirovannie osteosyntez s primeneniem biosovmestimikh polimernikh fiksatorov v lechenii perelomov dlinnikh kostey / Y.L. Kovalenko, A.B. Davidov, S.Y. Belikh [i dr.] // Ortopediya, travmatologiya i protezirovanie. - 1990. - № 2. S. 11-15. 3. Asamov M.S. Ekonomicheskaya effektivnost' primeneniya kompozitsionnikh materialov na osnove polikapromida v travmatologii i ortopedii / M.S.Asamov // Ortopediya, travmatologiya i protezirovanie. 2002. - № 3. - S. 137-138. 4. Dudko H.Ye. Mediko-sotcial'nie i ekonomicheskie aspekty khirurgicheskogo lecheniya perelomov polimernymi i metalopolimernymi konstruktsiyami / H.Ye. Dudko, Y.M. Rublenyk // Sovetskaya meditcina. - 1991. - № 12. - S. 43-45. 5. Tarasenko V.Y. Vozmozhnosti i perspektivy ispol'zovaniya uglerod-uglerodnikh implantatov (UUKM) v travmatologii i ortopedii / V.Y. Tarasenko, A.A. Tyazhelov // Zb. nauk. prats' XV z'yzda ortopediv-travmatologiv Ukrayiny. - D.: Lira, 2010. - S. 248. 6. Bioabsorbable materials in orthopaedics /George M. Kontakis, Joseph E. Pagkalos, Theodoros I. Tosounidis [et al.] //Acta Orthop. Belg. - 2007. - № 73. - P. 159-169.

\section{ОТДАЛЕННЫЕ РЕЗУЛЬТАТЫ ЛЕЧЕНИЯ БОЛЬНЫХ, ОСТЕОСИНТЕЗ КОТОРЫМ ПРОВОДИЛСЯ МЕТАЛИЧЕСКИМИ И БИ- ОДЕГРАДИРУЮЩИМИ ФИКСАТОРАМИ}

Резюме. Проведенные исследования с использованием клинических и рентгенологических методов исследования подтверждают, что патологических изменений в костной ткани в местах синтезированных консолидированных метаэпифизарных переломов, в оперативном лечении которых использовались фиксаторы, изготовленные из полимерных материалов полигликолида и полиамида-12, не выявлено на протяжении всего срока наблюдения - от 10 до 44 лет после оперативного вмешательства. Оба полимерных материала демонстрируют высокую биологическую совместимость, что позволяет безопасно использовать фиксаторы, изготовленные из данных материалов для остеосинтеза метаэпифизарных переломов.

Ключевые слова: остеосинтез переломов, биодеградирующие имплантаты, полигликолид, полиамид-12, длительные наблюдения.

\section{REMOTE RESULTS OF TREATMENT OF PA- TIENTS UNDERGONE OSTEOSYNTHESIS WITH METAL AND BIODEGRADABLE FIXA- TION DEVICES}

Abstract. Clinical and radiological examinations of patients after internal fixation of methaepyphyseal fracture have proved that both polymeric materials (polyglycolide and polyamide-12) possess high extent of biological compatibility. Polymeric fixation devices have not produced any negative effect on normal physiological regeneration of the bone tissue at the fractured segment within 10 to 44 years of followup. Therefore these materials can be safely used for manufacturing bone fixation devices for internal fixation fractures of methaepiphyseal areas.

Key words: internal fracture fixation, biodegradable implants, polyglycolide, polyamide- 12 , long term follow-up.

Higher State Educational Institution of Ukraine "Bukovinian State Medical University" (Chernivtsi)

Надійшла 30.01.2017 p. Рецензент - проф. Жук П.М. (Вінниця) 